\title{
"Extraordinary Administration" for business rescue in Italy: Admission requirements and value creation
}

\author{
PIERLUIGI SANTOSUOSSO \\ Faculty of Economics \\ Sapienza University of Rome \\ 9 Via del Castro Laurenziano, 00161 Rome \\ ITALY
}

\begin{abstract}
Large Italian firms in financial distress are admitted to the business rescue procedure called "Extraordinary Administration" with a view to preserving the business as a going concern when two objective requirements are met: at least two hundred employees and debts not less than two-thirds both of total assets and revenues. This study examines whether these selection criteria are adequate to identify large firms in terms of value creation. The analysis is motivated by the idea that social utility in the rescue of large firms should not be justified only by the number of employees, but also by the worth of the goods and services created by the firms. The sample is made up of 1,581 Italian manufacturing firms and four subsamples were analyzed for the three year period 2015-2017 using a set of logistic regression models. Research findings show that highly leveraged

firms eligible to go into "Extraordinary Administration" do not select large firms as measured by proxy variables that take into account value creation, such as total assets and/or revenues. On the other hand, hypothetical alternative selection criteria based on total assets and revenues identify large firms in terms of value creation but no statistical evidence was found to show how these firms are leveraged.
\end{abstract}

Key-Words: - Extraordinary Administration; business rescue; value creation; large firm; financial leverage.

Received: July 6, 2020. Revised: January 7, 2021 Accepted: January 16, 2021.

Published: January 26, 2021.

\section{Introduction}

Many large Italian companies (at least 121 from 2000) in financial distress have been admitted to the business rescue procedure called "Extraordinary Administration" (EA) pursuant to the Legislative Decree 270/99 [43]. The purpose of EA is to preserve corporate assets, through the continuation, reactivation or reconversion of entrepreneurial activities. Two main alternative approaches are suggested to achieve these results: a sales program for business complexes and the economic and financial restructuring of the company in order to preserve the business as a going concern. The direct running of the company is transferred to one or three judicial commissioners appointed by the Minister of Industry.

Not all financially distressed firms can benefit from EA. First, firms are admitted to the procedure if they present the prospect of preserving the business as a going concern. Second, admission to the procedure is reserved for large and highly leveraged firms. More specifically, the presence of two quantitative limits is required; a) firms must have had no less than two hundred employees in the last financial year; $b$ ) the total amount of debts must not be less than two-thirds both of total assets and of revenues in the last financial year. As a consequence, a large number of companies are excluded from EA. Firms with less than two hundred employees and/or with total debts that are less than two thirds of their assets and revenues are excluded even if they are considered large as far as the amount of assets and/or revenues is concerned.

The purpose of the present study is to analyze the scope of the objective requirements a) and b) by examining firm characteristics that distinguish companies that might go into EA from those that are excluded. More specifically, the main question posed in this paper is whether the aforementioned requirements are adequate to select large firms as identified by proxy variables that take into account value creation, such as the total amount of assets and/or revenues. The number of employees does not necessarily capture the size of the value created by firms and therefore the utility generated for their stakeholders. All things being equal, the greater the total amount of assets and/or revenues the higher the utility that a company generates for its shareholders, customers, creditors, employees and the community as a whole. In this perspective, although each country has specific insolvency regimes, the preservation of the business as a going concern is 
considered the main purpose of insolvency laws [41] together with the promotion of economic stability and growth [56, 39]. To address this question, the present study used a set of logistic regression models. The sample is made up of 1,581 Italian manufacturing firms and four subsamples were analyzed for the three year period 2015-2017.

The remainder of this study is organized as follows. The purpose of the research is described in the second section. The third section defines the firm sample and the methodology, the fourth section presents the results of the research. The last section provides some concluding remarks.

\section{Research question and background}

Italian firms in financial distress can benefit from EA when two objective requirements are met.

First, EA is reserved for large companies with a minimum number of two hundred employees at least in the last financial year. However, the selection criterion based on the number of employees fails to specifically consider the value created by firms. As is well-known, value creation is a central concept in economy. The creation of value can be examined for business owners, stakeholders [e.g., 24], customers, society and nations [38]. More specifically, it has been underlined that business rescue procedures provide an opportunity for financially distressed firms to add value to a society as a whole [36, 42]. Although a large number of traditional accounting-based and economic-based indicators have been used by academics and practitioners [for a review, 26], value creation can be measured by revenues and total assets. Revenues and total assets are two basic variables that are capable to capture the value creation, even for financially distressed firms that have negative net performances. The amount of revenues expresses the gross value produced by a firm and plays a key role in the process of value creation by identifying the exchange value of production $[12,14,50]$, whereas total assets indicate the book value of the investments that are estimated based on the company's future economic performance when the going concern principle is assumed.

Second, two indicators concerning firm leverage are also required pursuant to the Decree. The first, the ratio between debts and total assets, measures the ability of a firm to pay its debt with the amount of gross investments as presented on the balance sheet. Ceteris paribus, a rise in this indicator signals an increased use of financial leverage, interest expenses and therefore an increase in the financial risk and the related cost of capital [e.g., 5, 7, 57].
The second indicator, the ratio between debts and revenues, provides information on the firm's ability to meet the payment of debts with revenues generated by a company's normal business operations. All thing being equal, an increase in this indicator signals the difficulty of a firm to generate adequate revenues to cover the cost of interest and to repay its debts. In fact, a reduction in revenues and profitability is common among financially distressed firms [32, 33, 31]. Several studies have also revealed an inverse relationship between firm profitability and leverage. More specifically, numerous empirical studies have confirmed this association according to the Pecking order theory which assumes a preference order among the sources of financing [e.g., 46, 45, 54, 9, 4, 21, 48, $22,55,10,37,2,40]$. The most profitable firms prefer to finance new investments with internal funds coming from retained earnings rather than through debts or the issue of shares. Moreover, the probability of bankruptcy contributes to a further increase in costs and therefore to a reduction in profitability and firm's value [7, 59, 13]. Among these costs, there are the use of time spent to deal with issues related to bankruptcy [58], the loss of market share [47], the loss of suppliers and customers, a reduction in the ability of companies to obtain funding or issue new shares [5], a reduction in investment opportunities [15], changes in the commercial credit and debt policy $[44,25]$.

Despite the importance of the economic effects that EA has for thousands of workers, creditors and suppliers, the aforementioned objective requirements do not appear to have been adequately explored as yet. In addition to general discussions [e.g., 18, 20], EA has been addressed in several studies by examining the level of firm leverage and profitability in the period preceding admission to the procedure [17], the assessment of the intrinsic value of companies in Administration [35, 51], the analysis of the causes behind the crisis of the companies [19], the accuracy of the Z-Score model in forecasting the insolvency of companies in EA [6]. Moreover, several studies in other countries have examined the characteristics of business rescue as defined by similar procedures [e.g., 1, 23, 49] and the resolution methods of financial distress [e.g., 8, 28]. However, the different national approaches make difficult a comparative analysis. A wide variety of business rescue procedures across European Union and even more outside Europe exist [60, 61] and several attempts for a harmonization have been made [e.g., 53, 11]. In some countries there are procedures outdated, completely lacking and inefficient that 
unnecessarily prolong the life of companies whilst in other countries there is a multiplicity of procedures that increases the complexity in the insolvency law [41]. Despite the variety and limitations of some procedures, there is a general consensus that the purpose of the insolvency law is to preserve the business as a going concern [41].

Unlike previous papers published on EA, this is the first study to examine the legal requirements above mentioned. More specifically, the purpose of the present paper is to verify whether the objective requirements are adequate to select large firms as identified by proxy variables expressing value creation. The analysis is motivated by the idea that social utility in the rescue of large firms should not be justified only by the number of employees, but also by the worth of the goods and services created by the firms. With this perspective, two tests were carried out. First, this paper tested whether the amount of total assets and revenues distinguish firms that are eligible to go into EA from those that are excluded on the basis of the two requirements pursuant to the Decree. Second, this paper also used total assets and revenues as hypothetical admission requirements in order to verify whether these proxy variables of value creation are adequate to select highly leveraged firms as required by the Decree.

An affirmative response to this question is expected given a likely positive correlation between measures of firm size. The number of employees, total assets, revenues and other measures of firm size are often correlated with each other and their interchangeability has been examined in several studies [e.g., 30; 52, 27, 34, 3, 16]. In our firm sample of 1,581 Italian manufacturing firms, the highest positive correlation coefficient was found between revenues and total assets $(r=0.8414)$. There was also a high positive correlation coefficient between revenues and the number of employees $(r=0.7672)$, whereas a lower correlation is shown between total assets and the number of employees $(r=0.4917)$. Correlation coefficients were computed using the average values of the aforementioned measures of firm size for the threeyear period 2015-2017. On the other hand, even assuming that the number of employees is positively correlated with the other measures of firm size, the requirements concerning firm leverage could interfere with the selection of large firms expressed in terms of value creation. As has been mentioned above, a high level of firm leverage is often associated with low profitability.

\section{Firm sample and methodologies}

The present study examines manufacturing Italian firms included in section $\mathrm{C}$ of the classification of economic activity provided by the Italian National Institute of Statistics [29]. Data on the firm sample were obtained from Aida (Bureau van Dijk) which covers Italian companies with at least one million Euros of revenues. 91,741 firms were found in this group and a sample composed of firms that had no less than two hundred employees in the financial year 2017 pursuant to the Decree (2,090 firms) was selected. Firms whose data are not fully or partially available for the period 2015-2017 were excluded. Applying these selection criteria, 1,581 firms were selected. We found 252 firms in the aforementioned sample with debts greater than two thirds of both total assets and revenues (sample 1), whilst 1,329 firms did not meet the two indicators concerning firm leverage simultaneously (sample 2). The comparison was therefore made between firm sample 1 and 2. According to the logistic regression models (1a) and (1b), the analysis considers the binary dependent variable VARLEV (VARLEV identifies the companies with a leverage $\geq 2 / 3, Y=$ 1; VARLEV identifies the companies with a leverage $<2 / 3, Y=0$ ) and several independent proxy variables of firms characteristics.

The logistic regression models take the following general form:

$\operatorname{logit}(p$ VARLEV $)=\beta_{0}+\beta_{1} \operatorname{LnASS}_{i}+\beta_{2} \mathrm{ROD}_{i}+$ $\beta_{3} \mathrm{ACCPAY}_{i}+\beta_{4} \mathrm{FIXA}_{i}+\beta_{5} \mathrm{INTANGA}_{i}+$ $\beta_{6}$ ROTA $_{i}+\beta_{7}$ ROS $_{i}+\beta_{8}$ ATURN $_{i}$

(1a)

logit $(p$ VARLEV $)=\beta_{0}+\beta_{1} \operatorname{LnREV}_{i}+\beta_{2} \mathrm{ROD}_{i}+$ $\beta_{3}$ ACCPAY $_{i}+\beta_{4}$ FIXA $_{i}+\beta_{5}$ INTANGA $_{i}+$ $\beta_{6} \mathrm{ROTA}_{i}+\beta_{7} \mathrm{ROS}_{i}+\beta_{8} \mathrm{ATURN}_{i}$

(1b)

where:

$p \mathrm{VARLEV}=$ probability that VARLEV will occur;

LnASS $\quad=$ natural logarithm of total assets;

LnREV = natural logarithm of total revenues;

ROD = interest expenses divided by total debts;

ACCPAY = accounts payable divided by total liabilities;

FIXA $=$ tangible assets divided by total assets;

INTANGA = intangibles divided total assets; 


\begin{tabular}{|c|c|}
\hline ROTA & $\begin{array}{l}=\text { operating income divided by } \\
\text { total assets; }\end{array}$ \\
\hline ROS & $\begin{array}{l}=\text { operating income divided by } \\
\text { total revenues; }\end{array}$ \\
\hline ATURN & $=$ revenues divided by total assets \\
\hline
\end{tabular}

As the proxy variable of firm size, the natural logarithm of total assets (LnASS) was computed in model (1a) whereas the natural logarithm of total revenues (LnREV) was used in model (1b) in order to explore how the objective requirements capture value creation. The mutual exclusion of LnREV and LnASS in model (1a) and (1b) respectively was required to avoid multicollinearity. The average cost of debt was computed by dividing interest expenses by total debts (ROD). Amounts due to suppliers were measured by accounts payable divided by total liabilities (ACCPAY), where total liabilities are given by liabilities and shareholders' equity. The asset composition was measured as tangible assets divided by total assets (FIXA) and by intangible assets divided by total assets (INTANGA). Moreover, firm profitability was measured by the operating income divided by total assets (ROTA) and by the operating income divided by total revenues (ROS). The total asset turnover (ATURN), measured by revenues divided by total assets, was also examined as a proxy variable of firm efficiency. All the explanatory variables used in the regression analyses were computed as average values for the three-year period 2015-2017.

In order to enlarge upon this issue, the present study considered hypothetical selection criteria of firm size that are more adequate to express value creation. First, a comparison was made between firms with a high amount of total assets and firms with a low level, both presenting more than two hundred employees. More specifically, firms with a higher level of assets and firms with a lower level fall into the portion above and below the median of total assets in the sample of 1,581 firms, respectively. Therefore, the aforementioned sample was divided in two subsamples: sample 3 made up of firms with total assets greater than the median and sample 4 with lower values. Similarly, a second comparison was made between firms with more than two hundred employees that present a high level of total revenues and firms with the same large number of employees that have a lower amount of revenues. In other words, the sample of 1,581 firms was divided in two subsamples: sample 5 composed of firms with total revenues greater than the median and the sample 6 with lower values.

The analysis was carried out on the basis of the logistic regression models (2a) and (2b). First, the

regression analysis according to the logistic regression model (2a) considers the binary dependent variable SIZEASS as defined by total assets (SIZEASS identifies the firms with total assets greater than the median, $\mathrm{Y}=1$; SIZEASS identifies the firms with total assets lower than the median, $Y=0$ ) and a set of independent variables of firm characteristics. Second, the regression analysis according to the logistic regression model (2b) considers the binary dependent variable SIZEREV identified by total revenues (SIZEREV identifies the firms selected by total revenues greater than the median, $\mathrm{Y}=1$; SIZEREV identifies the firms with total revenues lower than the median, $\mathrm{Y}=0$ ) and a set of independent variables of firm characteristics. Firm leverage, as measured by debts divided by total assets (DEBTA), was included as an independent variable in both models. The logistic regression models have the following general form:

$$
\begin{gathered}
\operatorname{logit}(p \text { SIZEASS })=\beta_{0}+\beta_{1} \operatorname{LnREV}_{i}+ \\
\beta_{2} \text { ROD }_{i}+\beta_{3} \text { ACCPAY }_{i}+\beta_{4} \text { FIXA }_{i}+ \\
\beta_{5} \text { INTANGA }_{i}+\beta_{6} \text { ROTA }_{i}+\beta_{7} \text { ROS }_{i}+ \\
\beta_{8} \text { ATURN }_{i}+\beta_{9} \text { DEBTA }_{i}
\end{gathered}
$$

$$
\begin{gathered}
\operatorname{logit}(p \text { SIZEREV })=\beta_{0}+\beta_{1} \text { LnASS }_{i}+ \\
\beta_{2} \text { ROD }_{i}+\beta_{3} \text { ACCPAY }_{i}+\beta_{4} \text { FIXA }_{i}+ \\
\beta_{5} \text { INTANGA }_{i}+\beta_{6} \text { ROTA }_{i}+\beta_{7} \text { ROS }_{i}+ \\
\beta_{8} \text { ATURN }_{i}+\beta_{9} \text { DEBTA }_{i}
\end{gathered}
$$

$$
\begin{aligned}
\text { where: } & \\
p \text { SIZEASS }= & \text { probability that SIZEASS will } \\
& \text { occur; }
\end{aligned}
$$

All remaining terms are as defined previously.

The overall results suggest the absence of a multicollinearity problem for the variables used in models (1a), (1b), (2a) and (2b), as confirmed by the variance inflation factor (VIF). For models (1a) and (1b), VIF takes the minimum value for ROS (VIF = 1.003 ) and the maximum value for ATURN (VIF = 1.539). For models (2a) and (2b), VIF takes the minimum value for ROS (VIF $=1.015)$ and the maximum value for ATURN (VIF = 1.545).

\section{Empirical Results}

The descriptive statistics of the proxy variables of firm size, leverage and the number of employees are presented in table 1. Except for the value of 
DEBTA, no significant differences in the mean values of LnASS, LnREV and the number of employees were found between firm sample 1 (firms with a leverage $\geq 2 / 3$ ) and sample 2 (firms with a leverage $<2 / 3$ ). New evidence emerged when alternative firm selection criteria were considered. Firms in sample 3 (total assets $\geq$ median) showed an average value of LnREV and a number of employees higher than firms in sample 4 (total assets < median). Furthermore, the descriptive statistics revealed that LnASS and the number of employees are higher for firms in sample 5 (total revenues $\geq$ median) than in sample 6 (total revenues $<$ median). In sum, the requirements pursuant to the Decree do not seem to select large firms as measured by proxy variables of LnASS and LnREV. On the contrary, the firm sample selected on the basis of total assets presents a higher value of revenues and similarly the firm sample selected on the basis of total revenues shows a high value of assets. The samples identified according to total assets (sample 3) and revenues (sample 5) with values greater than the median are also composed of firms with a large number of employees.

Table 1 - Descriptive statistics. Firm size, leverage and employees

\begin{tabular}{|c|c|c|c|c|c|c|c|}
\hline Sample 1 & Mean & Median & St. Dev. & Sample 2 & Mean & Median & St. Dev. \\
\hline DEBTA & 0.780738 & 0.766812 & 0.089646 & DEBTA & 0.492364 & 0.492364 & 0.180386 \\
\hline LnASS & 11.7975 & 11.6245 & 1.071049 & LnASS & 11.67716 & 11.67716 & 1.049832 \\
\hline LnREV & 11.48072 & 11.3431 & 0.946964 & LnREV & 11.6911 & 11.6911 & 0.982435 \\
\hline $\mathrm{N}^{\circ}$ Employees & 542.4299 & 332.8333 & 706.2403 & $\mathrm{~N}^{\circ}$ Employees & 563.5054 & 563.5054 & 1181.472 \\
\hline Sample 3 & Mean & Median & St. Dev. & Sample 4 & Mean & Median & St. Dev. \\
\hline DEBTA & 0.517268 & 0.517268 & 0.205096 & DEBTA & 0.559416 & 0.559416 & 0.191426 \\
\hline LnASS & 12.47084 & 12.47084 & 0.847197 & LnASS & 10.92087 & 10.92087 & 0.549315 \\
\hline LnREV & 12.2683 & 12.2683 & 0.93415 & LnREV & 11.04525 & 11.04525 & 0.546106 \\
\hline $\mathrm{N}^{\circ}$ Employees & 816.0552 & 816.0552 & 1534.541 & $\mathrm{~N}^{\circ}$ Employees & 303.9131 & 303.9131 & 138.0417 \\
\hline Sample 5 & Mean & Median & St. Dev. & Sample 6 & Mean & Median & St. Dev. \\
\hline DEBTA & 0.538504 & 0.545235 & 0.195875 & DEBTA & 0.538153 & 0.549788 & 0.203066 \\
\hline LnASS & 12.34593 & 12.1496 & 0.957099 & LnASS & 11.04594 & 11.06777 & 0.678305 \\
\hline LnREV & 12.36059 & 12.13464 & 0.849833 & LnREV & 10.95451 & 11.0458 & 0.456594 \\
\hline $\mathrm{N}^{\circ}$ Employees & 824.8538 & 499.3333 & 1533.055 & $\mathrm{~N}^{\circ}$ Employees & 295.1034 & 260.8333 & 120.119 \\
\hline
\end{tabular}

Note. Sample 1: firms with debts greater than two thirds of both total assets and revenues. Sample 2: firms with debts lower than two thirds of both total assets and revenues. Sample 3: firms with total assets greater than the median. Sample 4: firms with total assets lower than the median. Sample 5: firms with total revenues greater than the median. Sample 6: firms with total revenues lower than the median. Firms in the samples present more than 200 employees. DEBTA: debts divided by total assets. LnASS: natural logarithm of total assets. LnREV: natural logarithm of total revenues. $\mathrm{N}^{\circ}$ Employees: number of employees in the last financial year (2017).

Table 2 shows the results of the regression analysis according to models (1a) and (1b). Although the coefficient of determination (Adjusted $\left.\mathrm{R}^{2}=0,209\right)$ revealed a high portion of unexplained deviation, the results of model (1a) indicated that the probability of having a "VARLEV $\mathrm{Y}=1$ " response (firms with a leverage $\geq 2 / 3$ ) increases as ROD and ACCPAY increase. The analysis also showed negative coefficients for ROTA, ATURN and LnASS. The regression results of model $(1 \mathrm{~b})$ confirmed that the probability of having a "VARLEV Y $=1$ " response increases as ROD and ACCPAY increase, whereas ROTA and ATURN decreases. No statistical evidence emerged for LnREV. In sum, the objective requirements do not select large firms as measured by proxy variables that express the value created by firms. On the contrary, firms eligible to go into EA present low values of LnAss in model 1(a) and negative coefficients of proxy variables of firm profitability (ROTA) and efficiency (ATURN) in both model (1a) and (1b) according to the Pecking order theory.

Table 3 provides the results of the regression analysis according to models (2a) and (2b). When SIZEASS is defined by the level of total assets according to model (2a), the positive coefficient for LnREV and ROTA suggested that the probability of having a "SIZEASS $\mathrm{Y}=1$ " response (firms with total assets $\geq$ median) increases as these variables increase. Vice versa, the negative coefficients for ROS, ATURN, ROD and ACCPAY suggested that the probability of having firms with a high value of total assets decreases as the above variables increase. When SIZEREV is defined by the level of total revenues according to model $(2 b)$, the regression results confirm that the probability of having a "SIZEREV $\mathrm{Y}=1$ " response (firms with total revenues $\geq$ median) increases as LnASS, 
ATURN and ACCPAY increase, whereas INTANGA decreases. In sum, the two hypothetical alternative selection criteria identified large firms as measured by LnASS and LnREV. Some differences emerged between the two criteria when specific firm characteristics were analysed, but no statistical evidence was revealed for firm leverage (DEBTA) on the basis of both model (2a) and (2b).

Table 2. Logistic regression results. Model (1a) and (1b).

\begin{tabular}{|c|c|c|c|c|c|c|c|c|c|c|}
\hline \multirow[b]{3}{*}{ const } & \multicolumn{5}{|c|}{ Model (1a) } & \multicolumn{5}{|c|}{ Model (1b) } \\
\hline & Coefficient & Std Error & $z$ & p-value & & Coefficient & Std Error & $z$ & $p$-value & \\
\hline & 1.99702 & 1.14753 & 1.7403 & 0.08181 & $*$ & 1.06559 & 1.02977 & 1.0348 & 0.30077 & \\
\hline LnAss & -0.184823 & 0.086873 & -2.1275 & 0.03338 & $* *$ & & & & & \\
\hline LnREV & & & & & & -0.126561 & 0.0870123 & -1.4545 & 0.14580 & \\
\hline ROD & 20.2119 & 4.92803 & 4.1014 & 0.00004 & $* * *$ & 19.9506 & 4.91557 & 4.0587 & 0.00005 & $* * *$ \\
\hline ACCPAY & 10.5451 & 1.15461 & 9.1331 & $<0.00001$ & $* * *$ & 10.5391 & 1.15007 & 9.1638 & $<0.00001$ & $* * *$ \\
\hline FIXA & -0.918489 & 0.565801 & -1.6233 & 0.10452 & & -0.837233 & 0.562033 & -1.4897 & 0.13632 & \\
\hline INTANGA & -0.776803 & 0.774478 & -1.0030 & 0.31586 & & -0.816898 & 0.774196 & -1.0552 & 0.29135 & \\
\hline ROTA & -8.77589 & 1.54072 & -5.6960 & $<0.00001$ & $* * *$ & -8.7976 & 1.49032 & -5.9032 & $<0.00001$ & $* * *$ \\
\hline ROS & 0.223498 & 0.542466 & 0.4120 & 0.68034 & & 0.223626 & 0.488733 & 0.4576 & 0.64727 & \\
\hline ATURN & -3.46136 & 0.342611 & -10.1029 & $<0.00001$ & $* * *$ & -3.22848 & 0.321358 & -10.0463 & $<0.00001$ & $* * *$ \\
\hline Adjusted $\mathrm{R}^{2}$ & 0.209004 & & & & & 0.207174 & & & & \\
\hline
\end{tabular}

Note. LnASS: natural logarithm of total assets. LnREV: natural logarithm of total revenues. ROD: interest expenses divided by total debts. ACCPAY: accounts payable divided by total liabilities. FIXA: tangible assets divided by total assets. INTANGA: intangibles divided total assets. ROTA: operating income divided by total assets. ROS: operating income divided by total revenues. ATURN: revenues divided by total assets. DEBTA: debts divided by total assets. *** Significant at the 0.01 level, ** Significant at the 0.05 level, * Significant at the 0.10 level (two-tailed).

Table 3. Logistic regression results. Model (2a) and (2b).

\begin{tabular}{|c|c|c|c|c|c|c|c|c|c|c|}
\hline \multirow[b]{3}{*}{ const } & \multicolumn{5}{|c|}{ Model (2a) } & \multicolumn{5}{|c|}{ Model (2b) } \\
\hline & Coefficient & Std Error & $z$ & $p$-value & & Coefficient & Std Error & $z$ & $p$-value & \\
\hline & -91.4827 & 5.83574 & -15.6763 & $<0.00001$ & $* * *$ & -91.0731 & 5.38685 & -16.9065 & $<0.00001$ & $* * *$ \\
\hline LnREV & 8.6578 & 0.548817 & 15.7754 & $<0.00001$ & $* * *$ & & & & & \\
\hline LnASS & & & & & & 7.21678 & 0.427266 & 16.8906 & $<0.00001$ & $* * *$ \\
\hline ROD & -16.8392 & 8.11021 & -2.0763 & 0.03787 & $* *$ & -11.8891 & 7.63062 & -1.5581 & 0.11922 & \\
\hline ACCPAY & -6.13271 & 1.56303 & -3.9236 & 0.00009 & $* * *$ & 2.89199 & 1.55869 & 1.8554 & 0.06354 & $*$ \\
\hline FIXA & -0.966377 & 0.77602 & -1.2453 & 0.21302 & & -0.441483 & 0.776389 & -0.5686 & 0.56960 & \\
\hline INTANGA & 0.712853 & 1.38049 & 0.5164 & 0.60559 & & -2.15804 & 1.15251 & -1.8725 & 0.06114 & * \\
\hline ROTA & 3.68848 & 1.7664 & 2.0881 & 0.03679 & $* *$ & 2.45471 & 2.55479 & 0.9608 & 0.33664 & \\
\hline ROS & -3.92144 & 0.545425 & -7.1897 & $<0.00001$ & **** & -0.145493 & 1.92694 & -0.0755 & 0.93981 & \\
\hline ATURN & -6.61834 & 0.484138 & -13.6704 & $<0.00001$ & $* * *$ & 6.52993 & 0.481998 & 13.5476 & $<0.00001$ & $* * *$ \\
\hline DEBTA & 0.465686 & 0.654733 & 0.7113 & 0.47692 & & 0.395958 & 0.635841 & 0.6227 & 0.53346 & \\
\hline Adjusted $R^{2}$ & 0.733460 & & & & & 0.713663 & & & & \\
\hline
\end{tabular}

Note. LnASS: natural logarithm of total assets. LnREV: natural logarithm of total revenues. ROD: interest expenses divided by total debts. ACCPAY: accounts payable divided by total liabilities. FIXA: tangible assets divided by total assets. INTANGA: intangibles divided total assets. ROTA: operating income divided by total assets. ROS: operating income divided by total revenues. ATURN: revenues divided by total assets. DEBTA: debts divided by total assets. *** Significant at the 0.01 level, ** Significant at the 0.05 level, * Significant at the 0.10 level (two-tailed).

\section{Concluding remarks}

The present study examined the objective admission requirements to EA pursuant to the Legislative Decree 270/99 for large financially distressed firms, namely the minimum number of two hundred employees and the amount of debts of no less than two-thirds both of total assets and revenues. Using a sample of 1,581 Italian manufacturing firms, the current paper verified whether these requirements are adequate to select large firms identified by proxy variables expressing value creation, such as total assets and revenues. Moreover, it was tested whether the total assets and revenues can be used as alternative hypothetical selection criteria to identify highly leveraged firms as required by the Decree
270/99. Other firm characteristics, such as firm profitability, the cost of debt and asset composition, were examined in order to assess the extent of the above mentioned requirements. Using a set of logistic regression models, four subsamples were analyzed for the three year period 2015-2017.

Research findings show that highly leveraged firms with more than two hundred employees that are eligible to go into EA do not select large firms as measured by proxy variables that take into account value creation. On the other hand, hypothetical alternative selection criteria based on total assets and revenues are adequate to identify large firms in terms of value creation, but no statistical evidence was found to show how these 
firms are leveraged. Moreover, regression analyses showed that several firm characteristics distinguish firms eligible to go into EA. A higher cost of debt (ROD) and exposure to suppliers (ACCPAY) characterized these firms from those that are excluded from the procedure. They also present low firm profitability (ROTA) and efficiency (ATURN) in line with the Pecking order theory.

Overall, the results of the present study can contribute to enriching the debate on the admission requirements to the business rescue procedure called "Extraordinary Administration". More specifically, this study has several implications. First, careful thought should be given to the social utility of the procedure in light of the suitability of the objective requirements to select firms that create value. In this perspective, proxy variables of value creation might be considered by policy maker as alternative admission requirements to the procedure. Second, this study can be a stimulus for policy maker, academics and practitioners to use proxy variables of value creation to assess the impact of business rescue procedures on stakeholders. Third, this study allows creditors and shareholders to learn more about the characteristics of the firms eligible to go into EA, such as firm leverage and profitability, the cost of debt, accounts payable and asset composition. For example, this information can be used in determining funding policies. All things being equal, the admission to a business rescue procedure reduces the risk of bankruptcy of a firm.

The study has, however, some limitations. First, the firm sample consists only of manufacturing companies, with the exclusion of banks and other financial companies. Second, the selection of some samples was carried out based on the median value of the assets and revenues presented by firms with more than two hundred employees. The identification of the amount of assets and revenues that distinguishes large companies could also be achieved using other selection criteria. Third, research findings are not immediately applicable to business rescue procedures in other countries given the variety of insolvency regimes.

\section{References:}

[1] Adebola, B., An invitation to encourage due consideration for the survivability of rescued businesses in the business rescue system of England and Wales, International Insolvency Review, Vol.26, No.2, 2017, pp. 129-152.

[2] Al Manaseer, M. F., Gonis, E., Al-Hindawi, R. M., \& Sartawi, I. I., Testing the Pecking Order and the Target Models of capital structure: evidence from UK, European Journal of Economics, Finance and Administrative Sciences, Vol.41, 2011, pp. 84-96.

[3] Al-Khazali, O. M., \& Zoubi, T. A., Empirical testing of different alternative proxy measures for firm size, Journal of Applied Business Research, Vol.21, No.3, 2005, pp. 79-90.

[4] Allen, D. E., The pecking order hypothesis: Australian evidence, Applied Financial Economics, Vol.3, No.2, 1993, pp. 101-112.

[5] Altman, E. I., A further empirical investigation of the bankruptcy cost question, The Journal of Finance, Vol.39, No.4, 1984, pp. 1067-1089.

[6] Altman, E. I., Danovi, A., \& Falini, A., La previsione dell'insolvenza: l'applicazione dello $\mathrm{Z}$ Score alle imprese in amministrazione straordinaria, Bancaria, Vol.69, No.4, 2013, pp. 24-37.

[7] Andrade, G., \& Kaplan, S. N., How costly is financial (not economic) distress? Evidence from highly leveraged transactions that became distressed, The Journal of Finance, Vol.53, No.5, 1998, pp. 1443-1493.

[8] Annabi, A., Breton, M., \& François, P., Resolution of financial distress under Chapter 11, Journal of Economic Dynamics and Control, Vol. 36, No.12, 2012, pp. 1867-1887.

[9] Baskin, J., An Empirical Investigation of the Pecking Order Hypothesis, Financial Management, Vol.18, No.1, 1989, pp. 26-35.

[10] Bharat, S. T., Pasquariello, P., \& Wu, G., Does asymmetric information drive capital structure decisions?, The Review of Financial Studies, Vol.22, No.8, 2009, pp. 3211-3243.

[11] Boon, G. J., \& Madaus, S, Toward a European Business Rescue Culture. In Jan Adriaanse \& Jean-Piere van der Rest (eds.), Turnaround Management and Bankruptcy: A Research Companion, Routledge, 2017, p. 238-258.

[12] Bowman, C., \& Ambrosini, V., Value creation versus value capture: towards a coherent definition of value in strategy, British Journal of Management, Vol.11, No.1, 2000, pp. 1-15.

[13] Bris, A., Welch, I., \& Zhu, N., The Costs of bankruptcy: chapter 7 liquidation versus Chapter 11 reorganization, The Journal of Finance, Vol.61, No.3, 2006, pp. 1253-1303.

[14] Bryant, L., Jones, D. A., \& Widener, S. K., Managing value creation within the firm: An examination of multiple performance measures, Journal of Management Accounting Research, Vol.16, No.1, 2004, pp. 107-131.

[15] Chen, G. M., \& Merville, L. J., An analysis of the underreported magnitude of the total indirect costs of financial distress, Review of 
Quantitative Finance and Accounting, Vol. 13, 1999, pp. 277-293.

[16] Dang, C., Li, Z. F., \& Yang, C., Measuring firm size in empirical corporate finance, Journal of Banking \& Finance, No.86, 2018, pp. $159-176$.

[17] Danovi, A., \& Falini, A., Profili di indebitamento e risultati reddituali nelle imprese assoggettate alla procedura di Amministrazione Straordinaria, Finanza, Marketing e Produzione, No.3, 2012, pp. 130159.

[18] Danovi, A., Crisi d'impresa e risanamento finanziario nel sistema italiano. Giuffré. Milano, 2003.

[19] Falini, A., Le cause della crisi d'impresa. Analisi dei fattori di crisi delle grandi imprese in Amministrazione Straordinaria, Sinergie, No.103, 2017, pp. 319-342.

[20] Falini, A., Le cause della crisi dell'impresa. Dalla definizione di un modello teorico alla sua verifica nell'esperienza delle imprese in amministrazione straordinaria, McGraw-Hill Education, Milano, 2018.

[21] Fama, E. F., \& French, K. R., Testing trade-off and pecking order predictions about dividends and debt, The Review of Financial Studies, Vol.15, No.1, 2002, pp. 1-33.

[22] Frank, M. Z., \& Goyal, V. K., Testing the pecking order theory of capital structure, Journal of Financial Economics, Vol.67, No.2, 2003, pp. 217-248.

[23] Gant, J. L., \& Kastrinou, A., The impact of austerity in the framework of corporate rescue and the rights of workers in the EU: A Road to Recovery?, International Insolvency Review, Vol.26, No.2, 2017, pp. 176-203.

[24] Garriga, E., Beyond stakeholder utility function: Stakeholder capability in the value creation process, Journal of Business Ethics, Vol.120, No.4, 2014, pp. 489-507.

[25] George, T. J., \& Hwang, C-Y., A resolution of the distress risk and leverage puzzles in the cross section of stock returns, Journal of Financial Economics, No. 96, 2010, pp. 56-79.

[26] Hall, J. H., Industry-specific determinants of shareholder value creation, Studies in Economics and Finance, 2016, pp. 1-19.

[27] Hopkins, H. D., Firm size: The interchangeability of measures, Human Relations, Vol. 41, No.2, 1988, pp. 91-102.

[28] Hotchkiss, E. S., John, K., Mooradian, R. M., \& Thorburn, K. S., Bankruptcy and the resolution of financial distress, in $\mathrm{B}$. Espen
Eckbo (ed.), Handbook of empirical corporate finance, pp. 235-287. Elsevier, 2008.

[29] Istat, Classificazione delle attività economiche Ateco 2007, Roma, Istituto nazionale di statistica, 2009.

[30] Jackson, J. D., \& Dunlevy, J. A., Interchanging measures of firm size: an asymptotic test and further results, Southern Economic Journal, 1982, pp. 764-768.

[31] Jiang, K., \& Wang, S., Firms in economic distress: survival strategies and economic factors, 2009. Available at: http://ssrn.com/ abstract $=1465181$.

[32] John, R., Lang, L. H. P., \& Netter, J., The voluntary restructuring of large firms in response to performance decline, The Journal of Finance, Vol.47, No.3, 1992, pp. 891-917.

[33] Kang, J, K., \& Shivdasani, A., Corporate restructuring during performance declines in Japan, Journal of Financial Economics, No.46, 1997, pp. 29-65.

[34] Kumar, K.B., Rajan, R.G., \& Zingales, L., What Determines Firm Size? (No. w7208). National Bureau of Economic Research, 1999.

[35] Lacchini, M. \& Trequattrini, R., La valutazione delle aziende coinvolte nelle procedure di amministrazione straordinaria ex d.lgs 270/1999: profili caratteristici e proposte innovative, Rivista dei Dottori Commercialisti, No.3/4, 2003, pp. 151-161.

[36] Lee, S. H., Peng, M. W., \& Barney, J. B., Bankruptcy law and entrepreneurship development: A real options perspective, Academy of Management Review, Vol.32, No.1, 2007, pp. 257-272.

[37] Lemmon, M. L., \& Zender, J. F., Debt capacity and tests of capital structure theories, Journal of Financial and Quantitative Analysis, Vol.45, No.5, 2010, pp. 1161-1187.

[38] Lepak, D. P., Smith, K. G., \& Taylor, M. S., Value creation and value capture: A multilevel perspective, Academy of Management Review, Vol.32, No.1, 2007, pp. 180-194.

[39] Madaus, S., The EU Recommendation on Business Rescue - Only Another Statement or a Cause for Legislative Action Across Europe? Insolvency Intelligence, Vol.27, No.6, 2014, pp. 81-85.

[40] Mazen, G., French firm's financing choices: towards a reconciliation of the static trade-off theory and the Pecking Order Theory?, International Journal of Financial Research, Vol.3, No.1, 2012, pp. 57-72.

[41] McCormack, G., Keay, A., Brown, S., \& Dahlgreen, J., Study on a new approach to 
business failure and insolvency. Comparative legal analysis of the Member States' relevant provisions and practices. No. JUST/2014/JCOO/PR/CIVI/0075, University of Leeds, 2016. Available at: https://ec. europa. eu/info/sites/info/files/insolvency_study_2016_ final_en.pdf.

[42] Miller, M. H., The Wealth transfers of bankruptcy: Some illustrative examples, Law and Contemporary Problems, Vol.41, No.4, 1977, pp. 39-46.

[43] MISE, Ministero dello Sviluppo Economico, Procedure aperte ai sensi del Decreto legislativo 270/99, 2018. Available at: https:// www.sviluppoeconomico.gov.it/index.php/it/i mpresa/vigilanza/amministrazionestraordinaria.

[44] Molina, C. A., \& Preve, L. A., Trade receivables policy of distressed firms and its effect on the costs of financial distress, Financial Management, Vol.38, No.3, 2009, pp. 663-686.

[45] Myers, S. C., \& Majluf, N., Corporate financing and investment decisions when firms have information that investors do not have, Journal of Financial Economics, Vol.13, No.2, 1984, pp. 187-221.

[46] Myers, S. C., The capital structure puzzle, Journal of Finance, No.39, 1984, pp. 575-592.

[47] Opler, T. C., \& Titman, S., Financial distress and corporate performance, The Journal of Finance, Vol.49, No.3, 1994, pp. 1015-1040.

[48] Panno, A., An empirical investigation on the determinants of capital structure: the UK and Italian experience, Applied Financial Economics, No.13, 2003, pp. 97-112.

[49] Pont, G. D., \& Griggs, L., A principled justification for business rescue laws: A comparative perspective (part II), International Insolvency Review, Vol.5, No.1, 1996, pp. 4779.

[50] Porter, M., Competitive Advantage, New York: Free Press, 1985.

[51] Romano, M., La valutazione d'azienda o di rami d'azienda nell'amministrazione straordinaria delle grandi imprese insolventi, Rivista dei Dottori Commercialisti, No.3, 2002, pp. 311-331.

[52] Shalit, S. S., \& Sankar, U., The measurement of firm size, The Review of Economics and Statistics, 1977, pp. 290-298.

[53] Stamegna, C., New EU insolvency rules give troubled businesses a chance to start anew. Members Research Service PE 623.548, European Union, 2018.
[54] Titman, S., \& Wessels, R., The determinants of capital structure choice, Journal of Finance, Vol.43, No.1, 1988, pp. 1-19.

[55] Tong, G., \& Green, C. J., Pecking order or trade-off hypothesis? Evidence on the capital structure of Chinese companies, Applied Economics, Vol.37, No.19, 2005, pp. 21792189.

[56] United Nations Commission on International Trade Law, Legislative guide on insolvency law, 2005. Available at: https://uncitral.un.org/en/library/publications

[57] Van Horne, J. C., \& Wachowicz Jr, J. M., Fundamentals of Financial Management. Edinburgh Gate, Harlow, Essex, UK: Pearson Education Limited, 2013.

[58] Warner, J. B., Bankruptcy costs: some evidence, The Journal of Finance, Vol.32, No.2, 1977, pp. 337-347.

[59] Weiss, L. A., Bankruptcy resolution: Direct costs and violation of priority of claims, Journal of Financial Economics, No.27, 1990, pp. 285-314.

[60] Wessels, B., \& Madaus, S., Business rescue in insolvency law in Europe: Introducing the ELI business rescue report, International Insolvency Review, Vol. 27, No. 2, 2018, pp. 255-280.

[61] Wessels, B., Business Rescue in Insolvency Law - Setting the Scene. In European Law Institute Projects Conference, 25 September 2014, Zagreb, Croatia.

\section{Creative Commons Attribution License 4.0 (Attribution 4.0 International, CC BY 4.0)}

This article is published under the terms of the Creative Commons Attribution License 4.0

https://creativecommons.org/licenses/by/4.0/deed.en US 